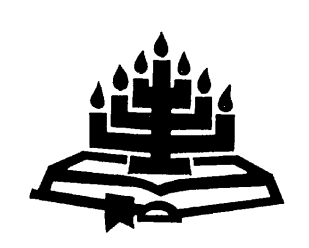

\title{
Oorreding in 1 Korintiërs 3:9c-23
}

\author{
A.H. Snyman \\ Departement Nuwe Testament \\ Universiteit van die Vrystaat \\ BLOEMFONTEIN \\ E-pos: ahsnyman@gmail.com
}

\section{Abstract \\ Persuasion in 1 Corinthians 3:9c-23}

This article is an attempt to analyse 1 Corinthians 3:9c-23 from a perpective different to approaches which tend to force ancient rhetorical categories on the letter. The analysis is done in terms of what is called "a grounded theoretical approach". This approach is briefly defined, followed by a description of the rhetorical situation of the letter and a systematic analysis of these fifteen verses. The focus is on the manner in which Paul argues, the types of argument he uses and the rhetorical techniques that could enhance the impact of his communication. It is shown that all these strategies and techniques enable him to achieve his rhetorical objectives in 1 Corinthians 3:9c-23.

The conclusion is that a text-based approach with its focus on the functional aspects of the text provides a good (or better) alternative to existing approaches which focus on the formal aspects of the text.

\section{Opsomming}

\section{Oorreding in 1 Korintiërs 3:9c-23}

Hierdie artikel is 'n poging om 1 Korintiërs 3:9c-23 te analiseer vanuit 'n perspektief wat verskil van benaderings wat neig om antieke retoriese kategorieë op die brief af te dwing. Die analise is gedoen in terme van " $n$ begronde teoretiese benadering". Die benadering word kortliks opgesom, gevolg deur 'n beskrywing van die retoriese situasie van die brief en 'n sistematiese analise van die vyftien verse, waarin gefokus word op die wyse waarop Paulus argumenteer, op die tipes argumente wat hy gebruik en op die retoriese tegnieke wat die trefkrag van sy kommunikasie verhoog. Daar word aangetoon hoe al hierdie strategieë en tegnieke hom in staat stel om sy retoriese doelwitte in 1 Korintiërs 3:9c-23 te bereik. 
Die gevolgtrekking is dat so 'n teksgebaseerde benadering met sy fokus op die funksionele aspekte van die teks, 'n goeie (of beter) alternatief bied tot bestaande benaderings, wat fokus op die formele aspekte van die teks.

\section{Inleiding}

Sedert 1979 is die retoriese analise van Paulus se briewe oorheers deur H.D. Betz se kommentaar op Galasiërs waarin hy gebruik maak van kategorieë ontleen aan die klassieke retoriese sisteem (exordium, narratio, propositio, probatio, ens.) om die brief te ontleed (Betz, 1979:16-23). Die kommentaar het gemengde reaksie ontlok. Barrett (1980:414-417) beskryf dit byvoorbeeld as 'n besondere mylpaal in die retoriese analise van die Skrif, maar wys tegelyk daarop dat Betz te veel maak van die Grieks-Romeinse retoriese sisteem en dat ander faktore ook in berekening gebring moet word. Joachim Classen, 'n erkende klassikus, waarsku dat retoriese kategorieë met omsigtigheid gebruik moet word, omdat Galasiërs 'n brief is en nie 'n toespraak nie. In sy bespreking van Betz se werk stel hy (Classen, 1993:288-289) dit soos volg:

It has become clear in the course of this paper, I hope, that rhetoric (oratory) and epistolography were regarded as two different fields in antiquity, and it seems advisable, therefore, to stay within the elaboration and presentation of their respective theory.

Later het hy wel van die klassieke retoriese kategorieë gebruik gemaak in sy analise van die Galasiërbrief, maar ook duidelik aangetoon dat dit nie alles in die brief kan verklaar nie (Classen, 2000:2324).

Betz se benadering het breë navolging gevind. Die gevolg was dat alle retoriese analises van die Skrif sedert 1979 hulleself in meerdere of mindere mate ten opsigte van sy voorstel moes posisioneer. Wat 1 Korintiërs betref is sy voorstel onder andere gevolg (en soms ietwat aangepas) deur Mitchell (1991), Smit (1993) en Witherington (1995), met verskillende resultate. Laasgenoemde is een van die belangrikste redes waarom navorsers na alternatiewe benaderings tot retoriese analise begin soek het. As dieselfde benadering lei tot soveel verskillende resultate, plaas dit die teoretiese regverdiging daarvan onder verdenking (sien 3.1.1 hieronder).

Een alternatief op Betz se benadering is die werk van Francois Tolmie (2005). Hierin word retoriek verstaan as 'n beskrywing van al die middele in die teks (appèlle, tipes argumente, ondersteunende teg- 
nieke, ens.) wat die skrywer gebruik om sy lesers tot sy standpunt te oorreed. ' $n$ Model word nie van buite op die teks afgedwing nie, maar alles in die teks wat bydra tot die proses van oorreding word geïdentifiseer en hulle funksies binne konteks beskryf. Hierdie sogenaamde teksgebaseerde benadering behels hoofsaaklik die volgende:

- 'n Beskrywing van die retoriese situasie van die brief. Dit is 'n samevatting van dit wat aanleiding tot die brief gegee het of wat Paulus in die brief wil bereik.

- 'n Deskriptiewe analise van hoe Paulus probeer om sy lesers te oorreed op basis van 'n begronde teoretiese raamwerk wat uit die volgende aspekte bestaan: die identifisering van die dominante retoriese strategie in elke gedeelte deur die primêre retoriese doel daarvan te beskryf en te bepaal hoe hy dit probeer bereik. In hierdie proses word veral gefokus op die tipe argumente wat hy gebruik en die wyse waarop hy argumenteer om sy lesers te oorreed. Eksegetiese kwessies word wel aangeraak, veral as Skrifverklaarders verskil oor die betekenis van 'n frase of uitdrukking van retoriese belang. Die fokus is egter op die retoriese funksie van die segging, nie op die eksegese as sodanig nie.

- Ten slotte word die sogenaamde retoriese tegnieke wat dien om die impak van die kommunikasie te verhoog, geïdentifiseer en hulle funksies beskryf (Tolmie, 2005:27-30).

Die doel van die artikel is om Tolmie se alternatiewe (funksionele) benadering tot retoriese analise op 1 Korintiërs 3:9c-23 toe te pas en sy waarde te bepaal deur die proses van oorreding in hierdie gedeelte aan die hand daarvan te beskryf.

\section{Retoriese konteks}

Die retoriese konteks waarin Paulus 1 Korintiërs geskryf het, kan soos volg gerekonstrueer word:

"Die mense van Chloë" (1 Kor. 1:11) het hom mondelings ingelig oor die situasie in Korinte en waarskynlik ook die brief, waarna in 1 Korintiërs 7:1 verwys word, aan hom oorhandig (SchüsslerFiorenza, 1987:395). Eerstens het Paulus hieruit te wete gekom van die onderlinge twiste in die gemeente, wat implikasies vir sy apostoliese gesag gehad het. Dit is onwaarskynlik dat 'n groep antiPaulus betogers die probleme veroorsaak het, soos Marshall (1987: 23-27) beweer. Die probleme was hoofsaaklik intern en het uit- 
geloop op partyskappe tussen die gemeentelede onderling (soos Schüssler-Fiorenza, 1987:397-398, Witherington, 1995:74 en veral Pogoloff, 1992:237 aangetoon het). Skrifverklaarders stem saam dat die belangrikste verskilpunt was oor wat dit beteken om pneumatikos te wees. Die Korintiërs het die spreek in tale as die basiese kriterium van spiritualiteit beskou, terwyl hulle belangstelling in sophia (wysheid) en gnosis (kennis) aan hulle besondere wysheid en meerdere kennis gegee het. Dit alles het uitgeloop op kauchesis (selfverheffing of roem) tussen die verskillende partye. Dit het radikaal ingedruis teen Paulus en sy boodskap en moes reggestel word.

In die tweede plek is die brief geskryf in reaksie op sekere praktiese aangeleenthede wat in die brief (waarna in 1 Kor. 7:1 verwys word) geopper is. Die belangrikste hiervan was die huwelik en seksualiteit (1 Kor. 5-7), vleis wat aan die afgode geoffer is (1 Kor. 8:1-11:1), aanbidding en die gawes van die Gees (1 Kor. 11:2-14:40), die opstanding (1 Kor. 15:12-57) en die insameling vir die heiliges in Jerusalem (1 Kor. 16:1-4). 'n Addisionele doel van die brief is om leiding oor hierdie, hoofsaaklik etiese, kwessies te gee.

In die brief probeer Paulus dus om sy lesers te oorreed om sy gesag as apostel (insluitend die waarheid van sy kruisevangelie en die aard van die kerk) te erken en so hulle partyskappe te laat vaar. Hy bespreek ook verskeie probleme waarmee hulle worstel en probeer hulle oorreed om sy instruksies te volg ten einde hulle nuwe lewe in Christus te verwerklik. In die brief gebruik hy verskeie effektiewe argumente en oorredingstegnieke. Om dit te ondersoek en te beskryf volgens 1 Korintiërs 3:9c-23, is die doel van hierdie artikel.

\section{Analise van 1 Korintiërs $3: 9 c-23$}

\subsection{Inleiding}

Twee sake verdien aandag voordat die proses van oorreding in besonderhede bespreek word:

Daar is nie eenstemmigheid tussen geleerdes wat Betz se benadering gebruik oor die afbakening van 1 Korintiërs nie. Mitchell (1991: 1) beskou byvoorbeeld 1 Korintiërs 3 as deel van die sogenaamde "proofs", wat strek van 1:1-15:57 en ingebed is in die liggaam of deliberatiewe argument van die brief, naamlik 1:10-15:57. Sy onderskei vier seksies in die probatio, te wete 1:18-4:21, 5:1-11:1, 11:2-14:40 en 15:1-57. Witherington (1995:94) weer, beskou 1:18-16:12 as die probatio van die brief en verdeel dit in nege argumente. 1 Korintiërs 
3 is deel van die eerste argument wat strek van 1:18-4:21. Die primêre doel van die probatio is om argumente ter ondersteuning van die redenaar se saak, soos gestel in die propositio, te bied (Witherington, 1995:44). Sowel Mitchell as Witherington stem saam dat die propositio van die brief te vind is in 1:10:

Ek doen 'n beroep op julle almal, broers, in die Naam van ons Here Jesus Christus, om almal eensgesind te wees en dat daar geen verdeeldheid onder julle moet wees nie, maar dat julle verenig moet wees in dieselfde gesindheid en met dieselfde oortuiging.

Hierdie benadering word deur twee punte geknel. Die eerste is die gebrek aan eenstemmigheid tussen geleerdes wat dieselfde kategorieë gebruik. Soos aangetoon, begin Mitchell en Witherington se probatio albei by 1:18, maar Mitchell s'n eindig by 15:57 en Witherington s'n by 16:12. Verder verskil hulle ook wat betref die afbakening van die peroratio van die brief. Vir Mitchell (1991:291-293) is die insameling vir die heiliges in Jerusalem in 16:1-12 deel van die afsluiting van die brief (wat strek van 16:1-24) en sy onderskei nie 'n afsonderlike peroratio nie, terwyl Witherington (1995:76) die insameling vir die heiliges as die laaste argument van die probatio beskou en 'n aparte peroratio afbaken, naamlik 16:13-18. Die gebruik van dieselfde retoriese kategorieë met verskillende resultate, plaas 'n vraagteken oor die teoretiese regverdiging van die benadering en is een van die belangrikste redes waarom Tolmie en andere na nuwe maniere begin soek het om die oorredingskrag van Paulus se briewe te beskryf.

'n Tweede knelpunt is dat die propositio in 1:10 nie die hele brief dek nie. Die probleem van verdeeldheid kom slegs in hoofstukke 1-4 aan die orde (Fee, 1988:47). In die res van die brief is daar geen verwysing daarna nie en daar word ook nie melding gemaak van Apollos of Petrus se rol in enige partyskappe nie. Die klassieke propositio is dus moeilik om op die brief toe te pas, omdat dit net 'n gedeelte van die probatio dek. Dit lyk meer produktief om Paulus se oorredingstrategieë in die brief self te identifiseer en te beskryf, in plaas daarvan om 'n eksterne retoriese model op die teks af te dwing en oor die formele afbakening van die brief in terme van klassieke kategorieë te begin redeneer.

Wat die afbakening van die brief in hierdie artikel betref, word die volgende weg gevolg. Dit is duidelik en word algemeen aanvaar dat die eerste vier hoofstukke oor partyskappe in die gemeente handel. In die vorige deel van die argument, naamlik 1:18-2:16, verduidelik 
Paulus die evangelie aan die hand van die kontras tussen goddelike en menslike wysheid. In 3:1-4 verander hy sy retoriese strategie van 'n verduideliking na 'n berisping. Die skeiding tussen 2:16 en 3:1 word ook gemerk deur die verandering van die eerste persoon meervoud na die sterk ka'gwv("wat my betref") aan die begin van 3:1. Hoofstuk 3 word afgesluit met twee aansporings in verse 18-22 en 'n soort doksologie in vers 23 , wat 'n duidelike aanduiding is dat die argument tot 'n einde gekom het. Hoofstuk 4 benader die verdeeldheid in die gemeente vanuit 'n ander hoek, naamlik die gesindheid van die Korintiërs teenoor Paulus self. Naas die doksologie in 3:23 word die skeiding tussen 3:23 en 4:1 ook gekenmerk deur 'n nuwe analogie, naamlik dié van 'n huishouding (4:1-3), sowel as deur asindeton in 4:1. Hoofstuk 3 vorm dus 'n onderskeidende retoriese fase in Paulus se hele argument.

Hoe kan die oorhoofse retoriese strategie in hoofstuk 3 beskryf word? Die saak waaroor dit in hierdie fase gaan, is die verdeeldheid onder die Korintiërs en die vraag hoe dit reggestel kan word. Retories word die fase as geheel deur die gebruik van twee analogieë gekenmerk, met 3:1-4 wat 'n oorgang vorm tussen 1:18-2:16 aan die een kant, en die twee analogieë in 3:5-9b en 3:9c-17 aan die ander kant. Die analogieë is ontleen aan die landbou en die bouwêreld onderskeidelik en word gebruik om die aard van die kerk en haar leierskap te verduidelik. Gevolglik kan die oorhoofse retoriese strategie in die fase beskryf word as 'n poging om die Korintiërs te oorreed om hulle partyskappe te laat vaar deur die aard van die kerk en haar leierskap reg te verstaan.

Hierdie fase kan in vier seksies verdeel word, ook afgebaken op grond van retoriese oorwegings, naamlik 3:1-4, 3:5-9b, 3:9c-17 en 3:18-23. Slegs die laaste twee seksies, wat handel oor die aard van die kerk, is vir die doel van die artikel ter sake. Redes vir die skeiding tussen 3:5-9b en 3:9c-17 is die verandering in analogie van 'n saailand na 'n gebou, asook die verandering in retoriese strategie van 'n verduideliking na 'n reeks waarskuwings. Die waarskuwings het betrekking op verskillende aspekte van die bouproses en is gerig aan almal wat aan die gebou werk, dit is, aan al die leermeesters en predikers in die kerk. Die gebou word beskryf as die tempel van God, waarin sy Gees woon (3:16-17). Die ondersteunende retoriese strategie in die seksie kan dus beskryf word as: "Waarsku die Korintiërs teen swak bouwerk aan die tempel van God".

Twee aansporings kenmerk seksie 3:18-23, waarin Paulus sy argument oor goddelike en menslike wysheid, asook oor die Korintiërs se roem op mense, kernagtig saamvat en hulle probeer oorreed om 
dit te laat vaar. Hierdie twee sake was die eintlike oorsake van verdeeldheid in die kerk. Die samevatting word afgesluit met die doksologie in 3:23 en die ondersteunende strategie hier beskrywe kan word as "Spoor hulle aan om menslike wysheid en roem te laat vaar".

Die res van die artikel word gewy aan 'n beskrywing van die wyse waarop Paulus in 3:9c-23 probeer om die Korintiërs tot sy siening van die kerk te oorreed en so hulle partyskappe te laat vaar.

\subsection{Analise}

\subsubsection{Korintiërs 3:9c-17: Waarsku die Korintiërs teen swak bouwerk aan die tempel van God}

Hier verander Paulus sy retoriese strategie van 'n verduideliking in $3: 5-9 b$ na drie waarskuwings en hy gebruik ' $n$ analogie met ' $n$ gebou om sy argument verder te voer.

Julle is die gebou van God ( $\theta \in$ ov oikodomh veś t e). Volgens die genade van God wat Hy my gegee het, het ek soos 'n goeie bouer die fondament gelê en 'n ander bou daarop; maar elkeen moet oppas hoe hy daarop bou. Want niemand kan 'n ander fondament lê as wat daar gelê is nie, dit is Jesus Christus. En as iemand op die fondament bou goud, silwer, kosbare stene, hout hooi, stoppels (c rus on, a jigur on, l igou timiou , xuka, cort on, kal amhn) - elkeen se werk sal aan die lig kom, want die dag sal dit aanwys, omdat dit deur vuur openbaar gemaak word; en die vuur sal elkeen se werk toets hoedanig dit is. As iemand se werk wat hy gebou het bly staan, sal hy sy loon ontvang (eijt ino to; ejg on mentî o \}ejpoikodomhs en, mis qon I hmyetai). As iemand se werk verbrand word, sal hy nie beloon word nie (eij tino to; ejgon katakahsetai, zhmiwghset ai) - alhoewel hy self gered sal word (a uf. $0 ;$ de; $s$ wqh s et a i), maar soos deur vuur.

Weet julle nie dat julle 'n tempel van God is en die Gees van God in julle woon nie? As iemand die tempel van God skend, sal God hom skend (eijtir ton naon tou' qeou f qeirei, $f$ qer eivtoût on of geo $\forall$ ). Want die tempel van God is heilig, en dit is julle. (1 Kor. 3:9c-17.)

Die kerk is vir Paulus nie 'n plek waar menslike wysheid verkondig word en mense op grond daarvan partyskappe vorm nie. Die kerk, so argumenteer hy in hierdie seksie, kan vergelyk word met 'n gebou waaraan mense, wat in diens van God staan, werk. In die analogie gaan dit inhoudelik oor drie aspekte van die bouproses: die 
fondament van die gebou (= Christus), die boumateriaal wat gebruik word (= die verkondiging van die kruisevangelie), en die soort gebou wat opgerig word (= die tempel van God). Retories klee Paulus sy argument in die vorm van waarskuwings in, wat betrekking het op al drie aspekte. Ten einde sy lesers te oorreed om die kerk reg te verstaan, maak hy ook hier van verskillende retoriese middele gebruik.

Die eerste en belangrikste oorredingsmiddel is ' $n$ argument gebaseer op analogie. Die analogie met 'n gebou oorheers die hele seksie (3:9c-17). Hierdie soort argument is effektief, omdat dit redelik maklik is om te volg. Indien die gehoor die konkrete basis van die analogie ken en daarmee saamstem, vind hulle dit maklik om die geestelike toepassing daarvan te verstaan (Tolmie, 2005:246). Cornelius (1998:56) skryf soos volg oor die analogie as oorredingsmiddel:

When the analogy is a fresh comparison that strikes the audience, it has enormous persuasive force. It derives its strength from its originality, its ability to make us see things from a new angle, from its aptness, its capacity to evoke reaction, and from its brevity, its ability to crystallize a whole range of problems into a single phrase or image.

Die analogie in die seksie word dus gebruik om die kerk vanuit 'n oorspronklike en nuwe gesigshoek te beskou en die Korintiërs langs hierdie weg te oorreed om hulle siening daarvan te verander.

Twee oorredingsmiddels word in sy waarskuwing oor die fondament van die gebou gebruik. Die eerste is ' $n$ argument gebaseer op goddelike handeling: Paulus het die fondament gelê "volgens die genade van God wat Hy my gegee het". Dit is aan die begin van 3:10 geplaas om dit uit te lig. Wat Paulus as stigter van die kerk gedoen het, het sy oorsprong in God en nie in enige mens nie. Deur die argument van goddelike handeling of ingryping voorop te stel en aan die stigting van die kerk te koppel, probeer Paulus die Korintiërs oorreed om nie enige prys op hom (of enige ander persoon) te stel nie. Hy verdien nie 'n spesiale posisie in die kerk wat tot partyskappe aanleiding kan gee nie. God alleen is die primêre rede vir die ontstaan en bestaan van die kerk. Met hierdie argument word die fokus op God, wat die vorige seksie so sterk oorheers het, voortgesit. Dit gaan om God aan wie die gebou behoort (3:9c), wat uit vrye guns vir Paulus aangestel het om die fondament te lê (3:10) en wat elkeen sal beloon volgens die kwaliteit werk wat hy gelewer het - vergelyk die "goddelike passiewe" katakahsetai, zhmiwghset ai en $s$ wqh set $a \mathrm{i}$ in 3:15. Wat Paulus gedoen het, het hy alleen op grond 
van God se genade gedoen. Gevolglik is daar geen rede vir roem of partyskappe nie. Binne konteks word die argument dus nie gebruik om Paulus se apostoliese gesag te beklemtoon (soos in 1:10), of om op sy bevoorregte posisie om 'n besondere taak te gaan verrig, te wys nie. Dit is soos Thiselton (2000:309) dit verstaan, maar presies die teendeel word egter bedoel.

Die waarskuwing dat elkeen moet oppas hoe hy op die fondament bou, word onverwags onderbreek deur die stelling dat Jesus Christus die fondament is (3:11). Die onderbreking skep probleme vir Skrifverklaarders en is die tweede belangrike oorredingsmiddel in die waarskuwing. Conzelmann (1975:75) beskou die stelling bloot as paradoksaal om aan te dui dat Paulus nie die fondament is nie. Fee (1988:139) weer, beskou die teks slegs as "something of an intrusion into the analogy proper", omdat die waarskuwing handel oor hoe daar op die fondament gebou word, nie oor die lê van die fondament nie. Volgens Wolff (2000:71) is vers 11 'n parentese tussen verse 10 en 12, wat op polemiese wyse die waarskuwing, om te let op hoe daar verder gebou word (einde van vers 10), begrond.

Watter interpretasie is korrek? Aangesien Paulus dikwels van parenteses gebruik maak (Gal. 2:2, 6, 8, 25; 4:15; Fil. 1:27; 2:12, ens.) en aangesien dit wat in die parentese gesê word belangrik is vir sy hele argument hier, lyk Wolff se interpretasie na die antwoord. In opvolging van 3:10 het die Korintiërs verwag dat Paulus sou uitbrei oor hoe daar op die fondament gebou moet word. Die feit dat hy egter onverwags invoeg dat Christus die enigste en onvervangbare fondament is, dui op die belangrikheid van die stelling. Dit beklemtoon dat, indien die gebou werklik die kerk van God wil wees, daar geen ander fondament moontlik is nie en alle verdere bouwerk by die fondament moet pas. Wolff is waarskynlik ook reg dat die parentese polemies verstaan moet word. Paulus rig hom nogeens tot sekere Korintiërs wat nie op die fondament bou nie, maar op menslike wysheid, en sê hulle die stryd aan.

Die volgende aspek van die bouproses handel oor die materiaal wat gebruik word en sluit af met die metafoor van vuur. Skrifverklaarders verskil oor die betekenis van die ses boumateriale wat gelys word. Fee (1988:140) gaan volledig in op die verklarings wat voorgestel is en kom tot die gevolgtrekking dat, in die lig van die konteks, dit nie vir Paulus gaan om die individuele items nie, maar om die verganklike kwaliteit van sommiges teenoor ander. Hy argumenteer dat "goud, silwer en kosbare stene" dít verteenwoordig wat versoenbaar is met die fondament, naamlik Jesus Christus en sy kruisevangelie. 
Wat tot niet sal gaan, is menslike wysheid ( $\mathrm{s}$ of $i$ ) ), wat deur "hout, hooi en stoppels" verteenwoordig word.

Retories is die metafoor wat hier gebruik word belangrik, asook die antitetiese parallelisme in 3:14-15a. Die oordeelsdag wat kom, dien as basis of rede vir die waarskuwing om daarop te let hoe gebou word. "Vuur" as metafoor kan verwys na reiniging of toetsing. Die konteks dui op laasgenoemde: die vuur sal oordeel oor die vakmanskap van die werkers deur te bepaal of kwaliteitmateriaal gebruik is of nie (Barrett, 1992:88). 'n Metafoor het basies dieselfde funksie as 'n analogie: dit voorsien die leser van 'n nuwe, ongewone gesigspunt en vestig so die aandag op die saak onder bespreking (Tolmie, 2005:99).

Die resultate van die toetsing word uitgespel in verse 14-15a en is reeds deur Conzelmann (1975:76) uitgewys as "an antithetical parallelismus membrorum". Die beskrywing van die resultate in terme van hierdie struktuur is belangrik vanuit 'n oorredingsperspektief, omdat dit die werk van goeie bouers treffend kontrasteer met dié van swak bouers en so die impak van die waarskuwing versterk. Dat dit om hulle werk gaan en nie om hulle as persone nie, word beklemtoon deur die herhaling van die term el gon (vier keer in verse 14-15), asook die byvoeging aan die einde van vers 15: "alhoewel hy self gered sal word, maar soos deur vuur". Ander retoriese tegnieke wat die argument ondersteun, word hieronder bespreek.

Die laaste aspek handel oor die soort gebou wat opgerig word en bevat die sterkste waarskuwing van almal - soos onder andere blyk uit die feit dat hy die Korintiërs vir die eerste keer sedert 3:9c direk aanspreek: "Weet julle nie dat julle 'n tempel van God is en die Gees van God in julle woon nie? As iemand die tempel van God skend, sal God hom skend. Want die tempel van God is heilig, en dit is julle." Paulus is steeds besig om aan die hand van die analogie met 'n gebou, die Korintiërs se foutiewe siening van die kerk reg te stel. Hier tipeer hy die gebou waaraan gewerk word as die tempel van God en waarsku sy lesers om dienooreenkomstig op te tree.

Drie sake is van retoriese belang. Eerstens gebruik Paulus in 3:17 ' $n$ argument gebaseer op eie kennis of ervaring. Hy herinner die Korintiërs aan dit wat hulle reeds weet. 'n Beroep op die leser se eie kennis is ' $n$ effektiewe oorredingsmiddel, omdat mense selde hulle eie, persoonlike belewenisse betwyfel. Hulle het nie 'n ander keuse as om saam te stem nie (Tolmie, 2005:101). Paulus gebruik dikwels hierdie soort argument in sy redevoerings met goeie gevolge (Gal. 3:1-5; 3:26-29; 4:6, 8, 29; Fil. 2:1-11; 2:22; 4:11b-12, ens.). So ge- 
beur dit ook hier. Deur 'n beroep te doen op hulle eie kennis en ervaring kan hulle nie ontken dat hulle die tempel van God is en die Gees van God in hulle woon nie. Die herinnering is van deurslaggewende belang vir die argument as 'n geheel en deur dit in die vorm van 'n vraag te giet, word die impak daarvan verder verhoog (Lenski, 1963:146).

Die tweede saak van belang is juis die retoriese vraag, wat getipeer kan word as 'n dial ekt i kon. Cronjé (1992:417-419) onderskei soos volg tussen 'n ej wthma en 'n dial ekt ikon:

- In die geval van 'n ejwthma val die fokus op die inhoud van die vraag en geen antwoord word verwag of verskaf nie. Dit word hoofsaaklik gebruik om die emosies van die spreker/skrywer uit te druk en die soort emosie moet telkens uit die konteks bepaal word.

- By 'n dialektikon word die vraag gevolg deur 'n antwoord wat die spreker/skrywer self verskaf. Dié soort vraag was baie gewild in antieke redevoerings waarin rasionele argumentasie aan die orde was. Die spreker/skrywer ontwikkel sy argument op 'n lewendige manier deur 'n gesprek te stimuleer, hetsy met homself of met iemand anders.

In 1 Korintiërs 3:16-17 beantwoord Paulus self die vraag in die vorm van 'n waarskuwing. As sodanig vorm dit 'n integrale deel van sy rasionele argumentasie: "Wees versigtig: julle wat die tempel van God skend (deur julle menslike wysheid en partyskappe), sal deur God self geskend word." Hoekom? Omdat die tempel, waaroor dit in die hele analogie gaan, heilig is. En die tempel van God is julle! Met hierdie stelling keer Paulus terug na die begin van die analogie in 3:9b: Julle is die gebou van God. Die dial ektikom is 'n kragtiger oorredingsmiddel as 'n gewone stelling en dien om gesprek te stimuleer.

'n Laaste oorredingsmiddel in 1 Korintiërs 3:16-17 is die wyse waarop die waarskuwing geformuleer is: "As iemand die tempel van God skend, sal God hom skend". Conzelmann (1975:78) wys daarop dat die onderliggende beginsel hier ooreenstem met die antieke "'n oog vir 'n oog en 'n tand vir 'n tand" en dat die betekenis van die stelling neerslag vind in die styl wat gebruik word: "The formal correspondence between the offense and God's reaction to it marks it as 'due retribution'”. Paulus se gebruik van erkende oorredingsmiddels en retoriese tegnieke is goed geboekstaaf; gevolglik is Conzelmann se interessante verklaring van die stelling verantwoord. 
Die volgende retoriese tegnieke versterk Paulus se argumentasie in 1 Korintiërs 3:9c-17:

- Asindeton kom voor tussen 3:9b en 3:9c ( $\theta \in \mathrm{ov}$ gewrgion, $\theta \in \mathrm{ov}$ oikodomhy, in die lys boumateriale in 3:12, en tussen 3:15 en 3:16. Dit is 'n erkende tegniek om woorde, frases en sinne van mekaar te onderskei en af te grens.

- Die plasing van woorde vir beklemtoning sluit $\theta \in 0 \hat{v}$ in 3:9 en a uf. $0 \nvdash$ aan die begin van 3:15c in.

- Twee chiasmes is besonder funksioneel en is reeds deur Skrifverklaarders uitgewys:

- Fee (1988:137) en Thiselton (2000:307) wys albei op die chiasme in 3:10-11, naamlik Paulus het die fondament gelê (A) - iemand anders bou daarop (B) - laat elkeen oppas hoe hy daarop bou (B) - die fondament is Jesus Christus (A). Die funksie van die chiasme is om die sleutelelemente van die bou-analogie uit te lig, te wete die fondament waarop gebou word (A) en die kwaliteit van die bouproses (B) (Fee, 1988:137).

- Die "formal correspondence" in 1 Korintiërs 3:17a en b waarop Conzelmann (1975:78) gewys het, is eijut $\sim(A)-t$ on na on tov̂ $\theta \in$ ov̂ (B) - f qeir ei (C) - f qer $\in \hat{\imath}(C)$ - toût on (B) 0) geo $\forall$ (A). Soos gemeld, dui dit vir hom op God se gepaste vergelding vir dié wat sy tempel skend.

- Dieselfde sintaktiese struktuur in opeenvolgende frases of parison (Nida et al., 1983:180) versterk die antitetiese parallelisme in 3:14 en 15a.

- In vers 15 eindig al drie die eerste frases op -h s et a i. Die stylfiguur staan bekend as homoioteleuton (Nida et al.,1983:176) en ondersteun ook die antitetiese parallelisme.

- Die plasing van f qeirei aan die einde van 17 a en f qerei aan die begin van 17b staan tegnies bekend as anastrophe (Nida et al., 1983:176). Dit word gebruik om 'n kontras te versterk 1 Korintiërs 7:27 is die beste voorbeeld daarvan.

Die ondersteunende retoriese strategie in 3:9c-17 kan dus saaklik beskryf word as: "Waarsku teen swak bouwerk aan die tempel van God". Die belangrikste oorredingsmiddel wat Paulus in die seksie gebruik is 'n argument gebaseer op analogie met 'n gebou: die fondament daarvan, die materiaal wat gebruik word en die soort gebou 
wat opgerig word is almal in die vorm van waarskuwings. Oorredingsmiddels in die waarskuwing oor die fondament van die gebou sluit in 'n argument gebaseer op goddelike handeling en 'n parentese. Die waarskuwing oor die materiaal wat gebruik word het as motivering die metafoor van vuur, terwyl die resultate van die toetsing beskryf word in die vorm van 'n antitetiese parallelismus membrorum. Oorredingsmiddels wat die soort gebou betref, sluit 'n retoriese vraag in, inclusio, 'n argument gebaseer op eie kennis of ervaring en die wyse waarop die skending van die tempel van God en sy vergelding formeel vergestalt word.

Retoriese tegnieke wat Paulus se kommunikasie in die seksie versterk, sluit asindeton, die plasing van woorde, chiasmes, homoioteleuton, parison en anastrophe in.

\subsubsection{Korintiërs 3:18-23: Spoor hulle aan om menslike wysheid en die roem in mense te laat vaar}

In hierdie seksie keer Paulus terug na die eintlike oorsake van verdeeldheid, naamlik die Korintiërs se voorkeur vir menslike wysheid en hulle roem in mense, wat sy hele argument van 1:10 af oorheers het. Dit vorm dus 'n soort inclusio, wat die argument in 1:103:17 kernagtig saamvat (Thiselton, 2000:319) Tegelyk verander Paulus sy retoriese strategie van waarkuwings in 3:9c-17 na twee gelykluidende aansporings, waarin hy daarop aandring dat sy lesers hulle nie ten opsigte van die twee sake moet laat mislei nie.

Laat niemand homself mislei nie (mhdei; $;$ ejut on ejapat a tw). As iemand onder julle meen dat hy wys is in hierdie wêreld, laat hom dwaas word, sodat hy wys kan word; want die wysheid van hierdie wêreld is dwaasheid by God (h)gar $s$ of i a tov̂ kos mou t outou mwria para;tw/qew, es tin). Want daar is geskrywe: Hy wat die wyse mense in hulle listigheid vang; en weer: Die Here ken die gedagtes van die wyse mense, dat dit nietig is. (1 Kor. 3:18-23.)

Twee sake is hier vanuit 'n oorredingsperspektief belangrik. Die eerste is die kontras tussen die wysheid van God en die wysheid van die wêreld, wat in 1 Korintiërs 1:17b en $c$ aan die orde gestel en in 1:18-2:16 volledig uitgewerk is. Die kontras is in die oorspronklike Grieks so skerp as moontlik gestruktureer (sien retoriese tegnieke hieronder) om te onderstreep dat die wysheid van hierdie wêreld en die wysheid van God mekaar volkome uitsluit. Daar is geen kompromie moontlik nie en die Korintiërs word aangespoor om hulle nie 
hieroor te laat mislei nie: in die kerk gaan dit slegs om die wysheid van God.

Om die waarheid te bewys, gebruik Paulus twee aanhalings uit die Skrif, naamlik Job 5:13 en Psalm 94:11. Die aanhalings, wat saamgebind word deur die term $\mathrm{s}$ of oi y stel dit dat God die listigheid van die wyse mense en hulle nietige gedagtes ken. Die Korintiërs sou dwaas wees indien hulle dit nie ook sou erken nie (Fee, 1988:152). 'n Argument gebaseer op die gesag van die Skrif is 'n erkende en effektiewe oorredingsmiddel (Tolmie, 2005:165-176 en 194-195). Deur sy argument te baseer op die skriftelike tradisie wat deur die meeste van sy lesers as gesaghebbend aanvaar word, spoor Paulus die Korintiërs effektief aan om die menslike wysheid te laat vaar en sodoende hulle partyskappe te oorwin.

Die tweede aansporing lees soos volg:

Laat niemand dan op mense roem nie, want alles behoort aan julle (pant a gar umôn eśtin); of dit Paulus is of Apollos of Sefas of die wêreld of lewe of dood of teenswoordige of toekomstige dinge - alles behoort aan julle (pant a umonn); maar julle behoort aan Christus, en Christus aan God. (1 Kor. 3:21-23.)

As deel van die inclusio wys hierdie aansporing terug na 1:29 ("sodat niemand voor Hom sou roem nie") en sy teendeel in 1:31 ("laat die wat roem, in die Here roem") (Thiselton, 2000:324). Skrifverklaarders verskil egter oor die vraag of pant a gar umown eśt in op oorheersing of besitting dui. Volgens Conzelmann (1975:80) is die stelling in pas met die Stoïsynse beginsel van "Alles behoort aan die wyse man", wat beteken dat hy in beheer is van alles. Die idee van heerskappy word ook by Barrett (1992:95-96) gevind. Daarteenoor beweer Lenski (1963:157) dat die frase nie oorheersing nie, maar besitting aandui, omdat Paulus se opvatting van die kosmos in toto verskil van dié van die Griekse en Romeinse filosowe: die heelal is ons s'n, maar ons heers nie daaroor nie. Die meeste Skrifverklaarders (vgl. Grosheide, 1954:94-95; Groenewald, 1967:55-56; Fee, 1988:153-155 en Thiselton, 2000:324-326) stem met laasgenoemde standpunt saam.

Watter interpretasie is korrek? Na my mening die tweede een, soos blyk uit die genitiewe konstruksies in $3: 9 ; 3: 16 ; 3: 17$ en $3: 23$, wat almal op besitting dui. Hierdie interpretasie van panta gar umôn es $\mathrm{t}$ in vind dus steun in die frase as geheel. Dit is retories belangrik dat die idee van besitting in 1 Korintiërs 3:21-23 in die vorm van 'n 
Steigerung gegiet is. Dit begin met die stelling dat alles aan die Korintiërs behoort - hulle behoort dus nie aan iemand soos Paulus of Apollos of Sefas nie. Inteendeel, hierdie persone behoort juis aan hulle! Verder behoort hulle weer aan Christus, en Christus, op sy beurt, aan God. So 'n tipe opbou is kenmerkend van 'n doksologie. Deur $\theta \in o \hat{v}$ aan die einde te plaas, beklemtoon Paulus God as die werklike eienaar van alles - wat alle roem op mense by voorbaat en in beginsel uitsluit. Op hierdie wyse word die Korintiërs finaal aangespoor om hulle roem in mense te laat vaar: hulle het geen grond daarvoor nie, omdat alles en almal, insluitend die kerk, aan God alleen behoort.

Die volgende retoriese tegnieke versterk Paulus se argument in die seksie 1 Korintiërs 3:18-23:

- Asindeton met mhdei $;$ elaut on ejapat atw in 3:18, onderstreep die breuk tussen die twee seksies.

- Oksimoron methjgar sofia tov kosmou toutrou mwria para; t w/qe $\hat{~}$ eśt in (3:19), is reeds uitgewys deur Lenski (1963:151). Soos in 1:25 dien die tegniek om die kontras tussen menslike en goddelike wysheid te verskerp.

- Die herhaling van pa at a (gar) umôn (eśt in) in 3:21 en 22 omraam die lys items wat aan die Korintiërs behoort en beklemtoon dit.

- Die lys items in 3:22 word aan mekaar gekoppel deur die partikel eife (polisindeton). Deur hierdie tegniek word die lys langer gemaak en word klem gelê op hoeveel dinge werklik aan die Korintiërs behoort.

Samevattend kan gestel word dat die ondersteunende oorredingstrategie in 1 Korintiërs 3:18-23 lees: "Spoor die Korintiërs aan om menslike wysheid en die roem in mense te laat vaar." In die eerste aansporing (18-20) probeer Paulus sy lesers oorreed deur menslike en goddelike wysheid so skerp as moontlik te kontrasteer en deur 'n argument gebaseer op die gesag van die Skrif te gebruik. Die tweede aansporing (21-23) is gegiet in die vorm van 'n Steigerung, terwyl asindeton, oksimoron, die herhaling van frases en polisindeton almal bydra om sy argumentasie te versterk.

\section{Konklusie}

Die bevinding van die studie is dat Tolmie se voorstel vir 'n teksgebaseerde retoriese analise van Paulus se briewe 'n sinvolle alter- 
natief bied op ander bestaande benaderings. In plaas daarvan om ' $n$ model van buite op die teks af te dwing, is 'n poging aangewend om al die oorredingsmiddels in 1 Korintiërs 3:9c-23 te identifiseer en hulle funksie binne konteks te beskryf. Sommige van die middels is reeds deur Skrifverklaarders geïdentifiseer, maar hulle funksies is selde beskryf. In hierdie artikel is gepoog om die leemte te ondervang deur die funksies in terme van die argument en/of konteks waarin die middele voorkom, te motiveer.

In die analise is gefokus op die manier waarop Paulus argumenteer, op die tipe argumente wat hy gebruik en op die retoriese tegnieke wat die impak van sy kommunikasie verhoog. Deur al die geïdentifiseerde retoriese middele en tegnieke probeer Paulus die Korintiërs oorreed tot die regte siening van die kerk om sodoende hulle partyskappe te laat vaar.

\section{Geraadpleegde bronne}

BARRETT, C.K. 1980. Galatians as an apologetic letter. Interpretation, 24(4):414-417.

BARRETT, C.K. 1992. A commentary on the first epistle to the Corinthians. 2nd ed. London: Black.

BETZ, H.D. 1979. Galatians: a commentary of Paul's letter to the churches in Galatia. Hermeneia: Fortress.

CLASSEN, C.J. 1993. St. Paul's epistles and Ancient Greek and Roman rhetoric. (In Porter, S.E. \& Olbricht, T.H., eds. Rhetoric and the New Testament: essays from the 1992 Heidelberg Conference. Journal for the study of the New Testament supplement, Series 90. Sheffield: JSOT Press. p. 264-291.)

CLASSEN, C.J. 2000. Rhetorical criticism of the New Testament. Tübingen: Mohr-Siebeck. (Wissenschaftliche Untersuchungen zum Neuen Testament, 128.)

CONZELMANN, H. 1975. 1 Corinthians: a commentary on the first epistle to the Corinthians. Hermeneia: Fortress.

CORNELIUS, E.M. 1998. The effectiveness of 1 Thessalonians: a rhetoricalcritical study. Stellenbosch: University of Stellenbosch. (Ph.D. dissertation.)

CRONJÉ, J.v.W. 1992. The strategem of the rhetorical question in Galatians 4:9-10 as a means towards persuasion. Neotestamentica, 26(2):417-424.

FEE, G.D. 1988. The first epistle to the Corinthians. Grand Rapids: Eerdmans.

GROENEWALD, E.P. 1967. Die eerste brief aan die Korinthiërs. Pretoria: NGKerk-Uitgewers.

GROSHEIDE, F.W. 1954. Commentary on the first epistle to the Corinthians. London: Marshall, Morgan \& Scott.

LENSKI, R.C.H. 1963. The interpretation of St. Paul's first and second epistles to the Corinthians. Minneapolis: Augsburg.

MARSHALL, P. 1987. Enmity in Corinth. Tübingen: Mohr-Siebeck. (Wissenschaftliche Untersuchungen zum Neuen Testament, 2/23.) 
MITCHELL, M. 1991. Paul and the rhetoric of reconciliation: an exegetical investigation of the language and composition of 1 Corinthians. Tübingen: Mohr-Siebeck. (Hermeneutische Untersuchungen zur Theologie, 28.)

NIDA, E.A., LOUW, J.P., SNYMAN, A.H. \& CRONJÉ, J.v.W. 1983. Style and discourse. Goodwood: National Book Printers.

POGOLOFF, S.M. 1992. Logos and Sophia: the rhetorical situation of 1 Corinthians. Atlanta: Scholars.

SCHÜSSLER-FIORENZA, E. 1987. Rhetorical situation and historical reconstruction in 1 Corinthians. New Testament studies, 33:386-403.

SMIT, J. 1993. Argument and genre of 1 Corinthians 12-14. (In Porter, S.E. \& Olbricht, T.H., eds. Rhetoric and the New Testament: essays from the 1992 Heidelberg Conference. Journal for the study of the New Testament supplement, Series 90. Sheffield: JSOT Press. p. 211-243.)

THISELTON, A.C. 2000. The first epistle to the Corinthians: a commentary on the Greek text. Grand Rapids: Eerdmans. (New International Greek Testament Commentary.)

TOLMIE, D.F. 2005. Persuading the Galatians: a text-centred rhetorical analysis of a Pauline letter. Tübingen: Mohr-Siebeck. (Wissenschaftliche Untersuchungen zum Neuen Testament, 2/90.)

WITHERINGTON, B. 1995. Conflict and community in Corinth: a sociorhetorical commentary on 1 and 2 Corinthians. Grand Rapids: Eerdmans.

WOLFF, C. 2000. Der erste Brief des Paulus an die Korinher. Leipzig: Evangelische Verlagsanstalt. (Theologischer Handkommentar zum Neuen Testament, 7.)

\section{Key concepts:}

\section{Corinthians 3:9c-23}

Pauline literature rhetorical situation rhetorical techniques text-based approach

\section{Kernbegrippe:}

1 Korintiërs 3:9c-23

Pauliniese literatuur

retoriese situasie

retoriese tegnieke

teksgebaseerde benadering 
